\title{
Article \\ Knocking out the Vitamin D Receptor Enhances Malignancy and Decreases Responsiveness to Vitamin D3 Hydroxyderivatives in Human Melanoma Cells
}

\author{
Ewa Podgorska ${ }^{1,2,+} \mathbb{D}$, Tae-Kang Kim ${ }^{1,+}{ }^{\mathbb{D}}$, Zorica Janjetovic ${ }^{1}$, Krystyna Urbanska ${ }^{2}$, Robert C. Tuckey ${ }^{3} \mathbb{D}^{\text {, }}$ \\ Sejong Bae ${ }^{4,5}$ and Andrzej T. Slominski ${ }^{1,6, *(D)}$
}

1 Department of Dermatology, University of Alabama at Birmingham, Birmingham, AL 35294, USA; epodgorska@uabmc.edu (E.P.); tkim@uabmc.edu (T.-K.K.); zjanjetovic@uabmc.edu (Z.J.)

2 Department of Biophysics, Faculty of Biochemistry, Biophysics and Biotechnology, Jagiellonian University in Kraków, 31-007 Kraków, Poland; krystyna.urbanska@uj.edu.pl

3 School of Molecular Sciences, University of Western Australia, Perth, WA 6009, Australia; robert.tuckey@uwa.edu.au

4 Department of Medicine, University of Alabama at Birmingham, Birmingham, AL 35294, USA; sbae@uabmc.edu

5 O'Neal Comprehensive Cancer Center, University of Alabama at Birmingham, Birmingham, AL 35294, USA

6 VA Medical Center, Birmingham, AL 35294, USA

* Correspondence: aslominski@uabmc.edu

+ Equal first authors.

check for updates

Citation: Podgorska, E.; Kim, T.-K.; Janjetovic, Z.; Urbanska, K.; Tuckey, R.C.; Bae, S.; Slominski, A.T. Knocking out the Vitamin D Receptor Enhances Malignancy and Decreases Responsiveness to Vitamin D3 Hydroxyderivatives in Human Melanoma Cells. Cancers 2021, 13 , 3111. https://doi.org/10.3390/ cancers13133111

Academic Editor: Suzie Chen

Received: 12 May 2021

Accepted: 16 June 2021

Published: 22 June 2021

Publisher's Note: MDPI stays neutral with regard to jurisdictional claims in published maps and institutional affiliations.

Copyright: (c) 2021 by the authors. Licensee MDPI, Basel, Switzerland. This article is an open access article distributed under the terms and conditions of the Creative Commons Attribution (CC BY) license (https:/ / creativecommons.org/licenses/by/ $4.0 /)$.
Simple Summary: Active forms of vitamin D3, including 1,25(OH $)_{2} \mathrm{D} 3,20(\mathrm{OH}) \mathrm{D} 3$ and $1,20(\mathrm{OH})_{2} \mathrm{D} 3$, inhibited cell proliferation, migration rate and the ability to form colonies and spheroids in the wild-type melanoma cell line, while cells with the vitamin D receptor (VDR) silenced showed an increased but not complete resistance to their action. Furthermore, silencing of the VDR in melanoma cells enhanced their proliferation as well as spheroid and colony formation and increased their migration rate. Previous clinicopathological studies have shown an inverse correlation between VDR expression, melanoma progression and poor outcome of the disease. Thus, the expression of VDR is not only necessary for the inhibition of melanoma growth by active forms of vitamin D, but the VDR can also function as a melanoma tumor suppressor gene.

Abstract: Vitamin D3 is not only involved in calcium and phosphate metabolism in humans, but it can also affect proliferation and differentiation of normal and cancer cells, including melanoma. The mechanism of the anti-cancer action of vitamin D3 is not fully understood. The nuclear vitamin D receptor (VDR) is crucial for the phenotypic effects of vitamin D hydroxyderivatives. VDR expression shows an inverse correlation with melanoma progression and poor outcome of the disease. In this study we knocked out the VDR in a human melanoma cell line using CRISPR methodology. This enhanced the proliferation of melanoma cells grown in monolayer culture, spheroids or colonies and their migration. Activated forms of vitamin $\mathrm{D}$, including classical $1,25(\mathrm{OH})_{2} \mathrm{D} 3,20(\mathrm{OH}) \mathrm{D} 3$ and $1,20(\mathrm{OH})_{2} \mathrm{D} 3$, inhibited cell proliferation, migration rate and the ability to form colonies and spheroids in the wild-type melanoma cell line, while VDR KO cells showed a degree of resistance to their action. These results indicate that expression of VDR is important for the inhibition of melanoma growth induced by activated forms of vitamin D. In conclusion, based on our previous clinicopathological analyses and the current study, we suggest that the VDR can function as a melanoma tumor suppressor gene.

Keywords: melanoma; vitamin D; vitamin D receptor; active forms of vitamin D; malignancy 


\section{Introduction}

Vitamin D3 (D3) is produced in the skin in two steps. Initially there is a photochemical reaction caused by the action of UVB radiation $(290-315 \mathrm{~nm}$ ) on 7-dehydrocholesterol (7DHC) in which the B ring is broken producing pre-vitamin D3 [1,2]. In the second reaction, vitamin D3 is formed from pre-vitamin D3 by its thermal isomerization at $37^{\circ} \mathrm{C}$ over several hours [3]. Both the UVB intensity and the level of skin pigmentation affect the rate of vitamin D3 production [4]. Vitamin D3 is a fat-soluble prohormonal secosteroid that has endocrine, paracrine and autocrine functions [5]. Melanin absorbs UVB limiting the production of D3, and the same effect is achieved with clothing and sunscreen [6-8]. Skin, more specifically the epidermis, has the full capacity to produce and activate vitamin D3 [9-11].

The liver and kidneys are the main organs in which two-step activation of vitamin D3 occurs [1]. In the liver, vitamin D3 is metabolized by a vitamin D 25-hydroxylase (CYP2R1 or CYP27A1) to 25-hydroxyvitamin D3 (25(OH)D3), which is the main form of vitamin $\mathrm{D}$ in serum. $25(\mathrm{OH}) \mathrm{D} 3$ is further metabolized by $1 \alpha$-hydroxylase (CYP27B1), mainly in the kidney proximal tubule, to $1 \alpha, 25$-dihydroxyvitamin $\mathrm{D} 3\left(1 \alpha, 25(\mathrm{OH})_{2} \mathrm{D} 3\right)$, the major hormonally active form of vitamin $\mathrm{D} 3$ [8]. $1 \alpha, 25(\mathrm{OH})_{2} \mathrm{D} 3$ is transported via vitamin D binding protein (VDBP) in the bloodstream to target tissues such as the intestine, bones and kidneys where it regulates calcium and phosphate absorption and reabsorption, respectively. The concentration of $1 \alpha, 25(\mathrm{OH})_{2} \mathrm{D} 3$ in the bloodstream regulates the expression of the inactivating enzyme, 25(OH)D3 24-hydroxylase (CYP24A1), which is induced when concentrations are high [12-14]. In addition to these classical pathways for vitamin D3 activation and inactivation, alternative metabolic pathways of vitamin D3 activation in the skin, including by keratinocytes [15] and dermal fibroblasts [16], are initiated by CYP11A1. Like $1,25(\mathrm{OH})_{2} \mathrm{D} 3$, the products of these pathways display anti-proliferative and differentiating abilities $[3,17,18]$. CYP11A1 is well known for catalyzing the hydroxylation of cholesterol at C22 and C20, followed by cleavage of the bond between C20 and C22 to generate pregnenolone, a common precursor for steroid hormones [19]. As well as the gonads and adrenal cortex, CYP11A1 is expressed in peripheral tissues such as the gastrointestinal tract, nervous system, immune system and skin [20,21]. It has more recently emerged that it is a vitamin D metabolizing enzyme with vitamin D serving as an alternative substrate to cholesterol [22,23]. The main metabolites of vitamin $\mathrm{D}$ that are formed by a single hydroxylation by CYP11A1 are 20(OH)D3, 22(OH)D3 and 17(OH)D3. These metabolites can be further hydroxylated by CYP11A1 to form $20,23(\mathrm{OH})_{2} \mathrm{D} 3,20,22(\mathrm{OH})_{2} \mathrm{D} 3,17,20(\mathrm{OH})_{2} \mathrm{D} 3$ and $17,20,23(\mathrm{OH})_{3} \mathrm{D} 3$. Moreover, the major product of this pathway, $20(\mathrm{OH}) \mathrm{D} 3$, may also serve as a substrate for CYP27A1, CYP24A1, CYP2R1 and CYP3A4 with hydroxylation occurring at C24, C25 or C26, while CYP27B1 hydroxylates most of these products at $\mathrm{C}-1 \alpha$ to produce the corresponding trihydroxyvitamin D metabolites. Overall, it has been estimated that this alternative metabolic pathway can produce more than 21 vitamin $D$ hydroxyl-metabolites $[24,25]$.

In target tissues, $1,25(\mathrm{OH})_{2} \mathrm{D} 3$ binds to the vitamin $\mathrm{D}$ receptor (VDR), a member of the nuclear receptor family, which includes ligand-activated transcription factors, and results in both genomic and non-genomic regulation of a variety of biological pathways [26-28]. The VDR is expressed in almost all tissues and cells, including the skin. Colston et al. [29] provided one of the first reports describing the presence of VDR outside of organs involved in calcium and phosphate homeostasis (intestines, kidneys and bone tissues), showing that the receptor is expressed in skin cell lines and in melanomas (malignant tumors originating from melanocytes) [30] and has anti-cancer properties. Subsequent experiments using human melanoma cell lines confirmed that the VDR is present in melanoma cells, although its expression level was heterogeneous between different cell lines [29]. The strongest expression of VDR was observed in normal skin, which decreased during progression of melanocytic lesions and during melanoma development. The VDR expression in perilesional skin was also significantly reduced in comparison to normal skin. Expression of VDR in various tumor tissues may suggest that it has an effect on tumorigenesis [31,32], 
for example in breast cancer [33] and lung cancer, and it might be related to the sex of patients [34]. The higher expression of VDR is also correlated with upregulated pathways that mediate the antitumor immunity and with downregulation of proliferative pathways [35].

Major types of skin cancer are basal and squamous cell carcinomas with melanoma being the most deadly skin neoplasm. The relationship between vitamin $\mathrm{D}$ and skin cancer is still under investigation. Vitamin D and novel vitamin D derivatives exhibit antiproliferative activities on different skin cells, including melanoma cells [36-41]. Studies showed that vitamin D has a protective effect for patients with melanoma [42-44]. In the skin, $1,25(\mathrm{OH})_{2} \mathrm{D} 3$ plays an important role in regulating the epidermal barrier function and in regulating the growth and cycle of the hair follicles and also has anti-cancer, antiproliferative and anti-inflammatory effects. It has recently been confirmed that it can inhibit skin cell death and DNA damage induced by UVR exposure. Due to its calcemic toxicity, the pharmacological use of $1,25(\mathrm{OH})_{2} \mathrm{D} 3$ is limited [45].

In 2010, Brożyna and co-authors showed that the level of tumor malignancy inversely correlates with VDR expression [31]. The strongest expression of VDR was observed in normal skin, and its expression decreased from normal skin through melanocytic nevi and melanoma to metastases. VDR expression in skin around moles and melanoma was also significantly reduced compared to normal skin [31], suggesting that it may serve as a marker of tumor progression [46,47]. Similar results were reported for breast cancer cells where VDR expression was inversely correlated to cancer malignancy [48], also seen in colon cancer [49]. In the current study we examined the effect of knocking out the VDR on melanoma malignant behavior.

\section{Materials and Methods}

\subsection{Sources of Vitamin D3 Compounds}

Both $1,25(\mathrm{OH})_{2} \mathrm{D} 3$ and $25(\mathrm{OH}) \mathrm{D} 3$ were purchased from Sigma. $1,20(\mathrm{OH})_{2} \mathrm{D} 3$ and $20(\mathrm{OH}) \mathrm{D} 3$ were enzymatically synthesized as described previously $[50,51]$.

\subsection{Culture of Melanoma Cells}

WM164, a human melanoma line, was a gift from Dr M. Herlyn (Wistar Institute, Philadelphia, PA, USA). The cells were cultured using DMEM media supplemented with $10 \%$ serum (fetal bovine serum while growing cells and charcoal-treated serum during incubation with vitamin D compounds), $1 \%$ antibiotics and $5 \mu \mathrm{g} / \mathrm{mL}$ insulin (SigmaAldrich, St. Louis, MO, USA). Cells were cultured in $75 \mathrm{~cm}^{2}$ plastic bottles (TPP-Techno Plastic Products AG, Trasadingen, Switzerland) with a filter in an incubator at $37^{\circ} \mathrm{C}$ with $5 \% \mathrm{CO}_{2}$.

\subsection{CRISPR/Cas Knock out of the VDR}

The clustered regularly interspaced short palindromic repeats (CRISPR) genetic engineering method was carried out to knock out VDR expression in the WM164 cell line. The method was used to change the cellular genome specifically to knock out the expression of the VDR gene. The cells were plated in $25 \mathrm{~cm}^{2}$ flasks and cultured for $24 \mathrm{~h}$, followed by replacing the medium with medium containing polybrene $(10 \mu \mathrm{g} / \mathrm{mL})$ to stabilize lentivirus and incubate with human VDR sgRNA CRISPR All-in-One Lentivirus or scrambled lentivirus (Applied Biological Materials Inc., Richmond, BC, Canada) for the next $24 \mathrm{~h}$. The sgRNA was designed to target all 3 isoforms of VDR (NM_000376, NM_001017535, NM_001017536) (Figure 1A). After incubation, the medium was changed to a medium containing $5 \mu \mathrm{g} / \mathrm{mL}$ puromycin for selection of lentivirus transduced cells. The resulting cells with the VDR gene knocked out are designated as WM164 VDR KO, and the cells transduced with an "empty" lentivirus served as a control (WM164 scramble). VDR expression was checked for scramble and VDR KO lines before experiments were performed and further every 4 months after lentivirus treatment to ensure that VDR was not expressed in the WM164 KO. 
A

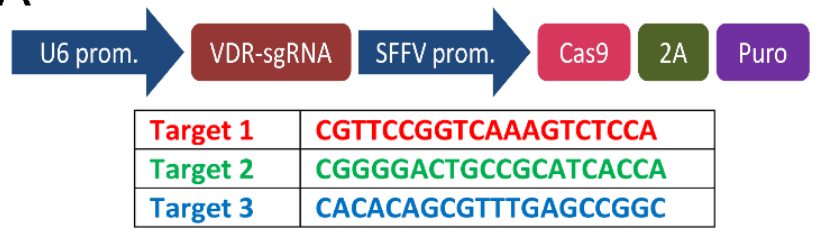

B

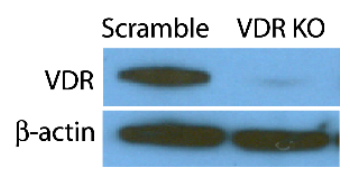

Figure 1. VDR knockout using CRISPR technology. (A) Main part of construct for generating sgRNA (top) and target sequence for VDR knockout (bottom). The lentivirus was produced by Applied Biological Materials Inc. (Richmond, BC, Canada) using pLenti-U6-sgRNA-SFFV-Cas9-2A-Puro. (B) Western blot of the VDR in scramble and VDR KO cells using $\beta$-actin as a loading control.

\subsection{Western Blot Analysis of VDR Expression}

The Western blot method used in the present study has been described previously [52]. VDR (D-6) primary monoclonal anti-mouse antibody (Santa Cruz Biotechnology, Inc., Dallas, TX, USA) was used after a 1:200 dilution with 5\% skim milk in TBS-T buffer. mIgGk BP-HRP (Santa Cruz Biotechnology, Inc., Dallas, TX, USA) in 5\% skim milk (1:5000) was used as secondary antibody. Immuno-reactivity was detected using SuperSignal West Pico Chemiluminescent Substrate (Thermo Fisher Scientific, Waltham, MA, USA). The original Western Blots data was shown in the Supplementary Materials.

\subsection{MTS Assay of Melanoma Cell Proliferation}

Both scramble and VDR KO cell types were plated onto a 96-well plate at a density of $0.5 \times 10^{3}$ cells/well. Cells were incubated with selected vitamin D3 compounds at concentrations from $10^{-7}$ to $10^{-10} \mathrm{M}$ for period of $24 \mathrm{~h}$. MTS solution (Promega, Madison, WI, USA), $10 \mu \mathrm{L} /$ well, was then added and after $3 \mathrm{~h}$ the absorbance was measured using a Cytation 5 plate reader at $490 \mathrm{~nm}$. Absorbances were analyzed using Gen 5.3 software (BioTek, Winooski, VT, USA).

\subsection{Cell Counting}

The VDR KO and scrambled cells were seeded onto 24-well plates in triplicate, at $1 \times 10^{4}$ cells per well and counted daily using a hemocytometric chamber. The cells were washed with PBS solution and then incubated with $100 \mu \mathrm{L}$ trypsin $0.25 \%$ (Corning, NY, USA) for $5 \mathrm{~min}$. To stop cell trypsinization medium with $10 \%$ FBS was added, 400 or $900 \mu \mathrm{L}$ (depending on the number of cells). A $10 \mu \mathrm{L}$ aliquot of cells was taken and the cells were counted under a microscope using a Bürker hemocytometer. A second method of checking the proliferation was to measure cell surface area before counting them manually in a hemocytometric chamber. Wells were photographed using a Cytation 5 instrument (BioTek, Winooski, VT, USA) and the covered surface area was analyzed using Gen 5.3 software (BioTek, Winooski, VT, USA).

\subsection{Analysis of Spheroid Formation in Culture}

The WM164 cells were cultured for the formation of spheroids in DMEM containing $20 \mathrm{ng} / \mathrm{mL}$ epidermal growth factor, $10 \mathrm{ng} / \mathrm{mL}$ basal fibroblast growth factor, $5 \mu \mathrm{g} / \mathrm{mL}$ insulin and $0.4 \%$ bovine serum. Cells at a concentration of $5 \times 10^{3} / \mathrm{mL}$ were added to the medium and incubated with factor B27, growth factor to support the formation of spheroids in cell lines, at a dilution of 1:50 (Gibco, Waltham, MA, USA). The cells were plated onto a 96 well ultralow attachment plate (Costar ${ }^{\circledR}$, Corning, NY, USA) $200 \mu \mathrm{L} /$ well. The wells at the edge of the plate were filled with PBS to ensure adequate humidity inside the plate. After a week of incubation, the resulting spheroids were counted manually and using a Cytation 5 instrument (BioTek, Winooski, VT, USA). Data were analyzed using Gen 5.3 software (BioTek, Winooski, VT, USA). 


\subsection{Colony Formation Assay}

The WM164 cells were seeded at $3 \times 10^{3} /$ well, onto a 12-well culture plate (TPP) using DMEM medium containing selected vitamin D3 derivatives $\left(1,25(\mathrm{OH})_{2} \mathrm{D} 3,25(\mathrm{OH}) \mathrm{D} 3\right.$, $1,20(\mathrm{OH})_{2} \mathrm{D} 3$, or $\left.20(\mathrm{OH}) \mathrm{D} 3\right)$ at concentrations ranging from $10^{-7}$ to $10^{-10} \mathrm{M}$. After three days, the medium was changed, and 7 days after seeding the cells were stained with crystal violet and the number of colonies formed was analyzed using Gen 5.3 software (BioTek, Winooski, VT).

\subsection{Cell Migration Assay}

The VDR KO and scrambled cells were seeded at $2 \times 10^{4}$ cells in $70 \mu \mathrm{L}$ onto 3 special removable silicone wells (ibidi ${ }^{\circledR}$, Gräfelfing, Germany) in a 24-well plate. Cells were incubated in serum-free medium for $24 \mathrm{~h}$. At $95 \%$ confluence, the wells were removed, thus creating two scratches in every well, each $5 \mu \mathrm{m}$ wide. After the formation of scratches, the cells were incubated with selected vitamin D3 derivatives at a concentration of $10^{-7} \mathrm{M}$, or ethanol as a control. The plate was placed in a Cytation 5 reader at $37^{\circ} \mathrm{C}$ and $5 \% \mathrm{CO}_{2}$ where photos of each well were taken simultaneously every hour for $70 \mathrm{~h}$. Migration analysis was performed using Gen 5.3 software.

After pictures were taken, we defined a rectangle with an area $10 \mu \mathrm{m}^{2}$ on and around the scratch and counted the area occupied by the cells. The size of the rectangle occupied by cells directly correlated with the scratch that was covered.

\subsection{Statistical Analysis}

Results are presented as the mean \pm SEM. Calculations of statistical significance of the tests were carried out with GraphPad Prism 4 (San Diego, CA, USA). Depending on the data, a two-way ANOVA or Student's $t$-test analysis was performed. Given the exploratory nature of this study, there was no correction made for multiple testing, and statistical significance was set at $p$ value $<0.05$. Values are $p<0.05^{*}, p<0.01^{* *}, p<0.001^{* * *}, p<$ $0.0001^{* * * *}$.

\section{Results}

In 2010, Brożyna and co-authors showed that as the malignancy of cancer increases, the expression of the VDR decreases in patients with skin melanoma [31]. To further investigate this relationship, we knocked out the VDR gene in WM164 melanoma cells using CRISPR/Cas methodology as described in Materials and Methods. The lack of vitamin D receptor expression was confirmed by Western blotting, which showed that unlike the scramble control, no protein corresponding to the VDR was present in the WM164 KO cells (Figure 1B and Figure S1).

\subsection{VDR Expression Affects Cell Proliferation, Colony and Spheroid Formation}

After confirming that the VDR was knocked out in WM164 cells, we investigated how VDR expression affects cell proliferation, colony and spheroid formation. Daily cell counting using a hemocytometric chamber and daily measurements of the space occupied by the cells confirmed that knocking out the VDR in WM164 melanoma cells accelerates their multiplication rate. The number of VDR KO cells was significantly higher than for scramble cells from days 2 to 5 of the experiment, being more than double on days 3 and 4 (Figure 2). The average cell surface area for VDR KO cells was also significantly higher than for scramble controls on days 4 and 5 (Figure 3).

To determine the anti-proliferative effect of vitamin $\mathrm{D} 3$ derivatives, scramble and VDR KO cells were incubated for $24 \mathrm{~h}$ with $1,25(\mathrm{OH})_{2} \mathrm{D} 3,1,20(\mathrm{OH})_{2} \mathrm{D} 3$ or $20(\mathrm{OH}) \mathrm{D} 3$ at concentrations of $10^{-9}$ and $10^{-10} \mathrm{M}$. Proliferation was measured using the MTS assay, which measures mitochondrial activity. Vitamin D3 derivatives had a small but significant inhibitory effect on the proliferation of the scramble cell line, typically about $20 \%$, but they did not have a significant effect on the VDR KO cells (Figure 4). 


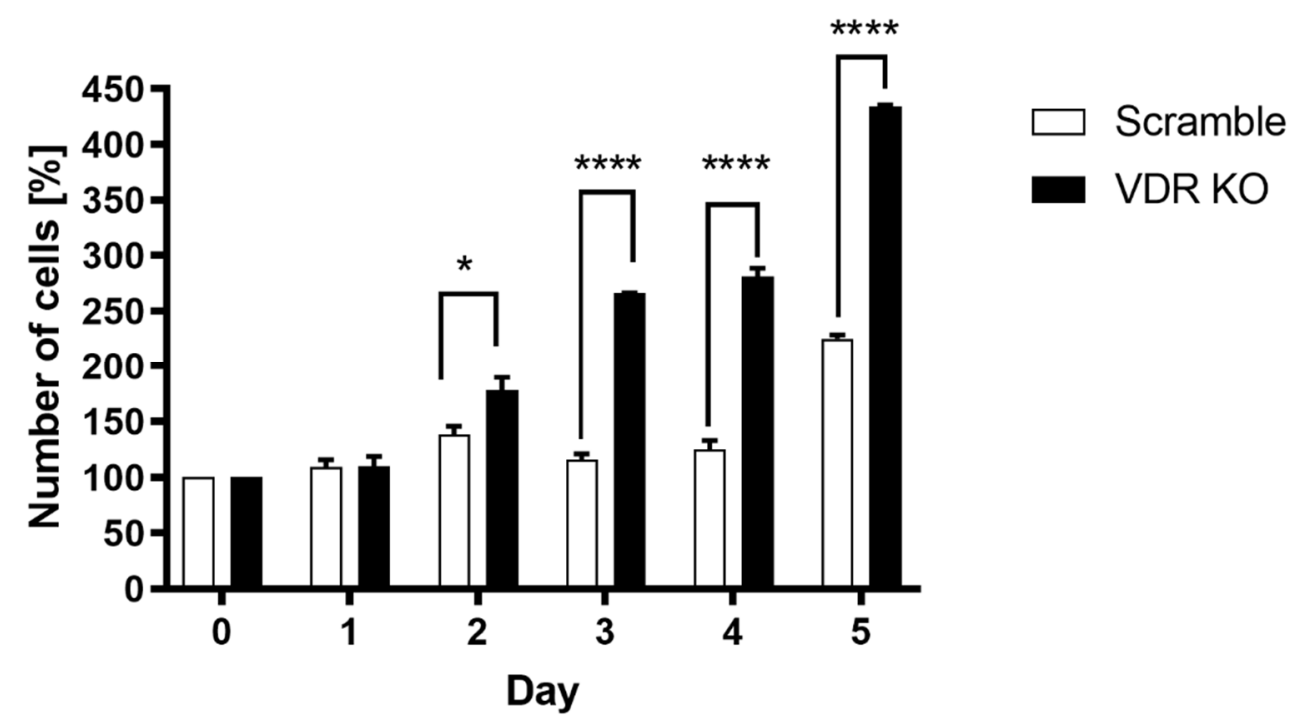

Figure 2. Proliferation rate of VDR KO WM164 cells versus scramble controls. The number of cells (\% relative to day 0 ) was determined each day for 5 days from seeding for both cell types, which were seeded at the same initial concentration. Statistical significance was determined using the $t$-test, $p<0.05^{*}, p<0.0001^{* * * *}, n=6$.

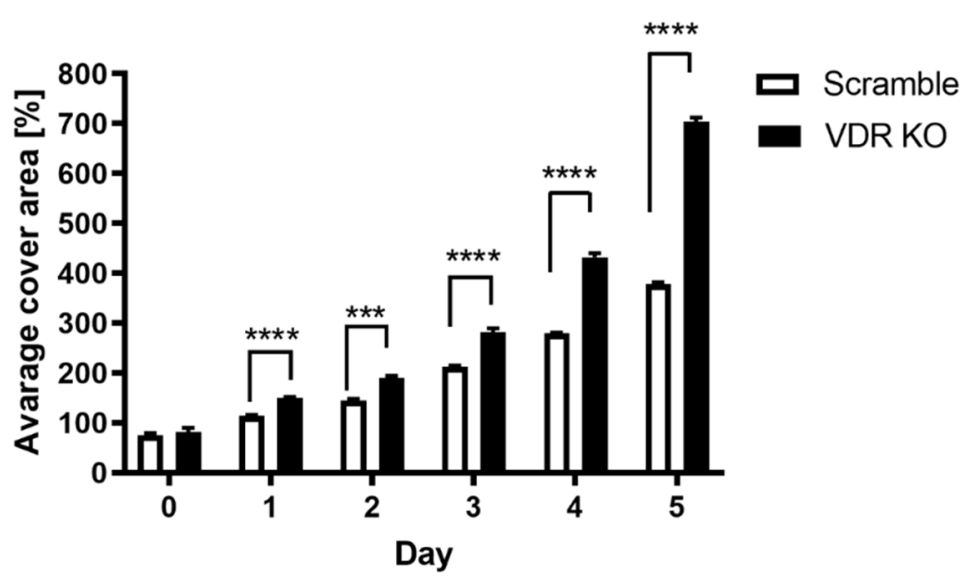

Figure 3. The average surface area covered by scramble and VDR KO WM164 cells over 5 days of growth. Cell surface area was measured for scramble controls and VDR KO cells over 5 days as in Figure 2, with both cell types originally being seeded (day 0 ) at the same concentration. Statistical significance was determined by $t$-test, $p<0.001^{* * *}, p<0.0001^{* * * *}, n=6$.

After seeing the effects on cell proliferation, we checked the ability of VDR KO cells to form colonies. The VDR KO produced approximately $40 \%$ more colonies than the scramble control (Figure 5). The influence of vitamin D3 derivatives on colony formation by WM164 VDR KO cells compared to scramble controls was also examined (Figure 6). Cells were incubated for 7 days with selected vitamin D3 derivatives $\left(20(\mathrm{OH}) \mathrm{D} 3\right.$ and $\left.1,20(\mathrm{OH})_{2} \mathrm{D} 3\right)$ at concentrations from $10^{-7}$ to $10^{-10} \mathrm{M}$. Both secosteroids significantly decreased colony formation by the scramble melanoma cells at all concentrations tested compared to the ethanol control (Figure 6A), by up to about $75 \%$ at the highest concentrations. In contrast, $20(\mathrm{OH}) \mathrm{D} 3$ and $1,20(\mathrm{OH})_{2} \mathrm{D} 3$ had lesser effects on colony formation by the VDR KO cells (Figure $6 \mathrm{~B}) .20(\mathrm{OH}) \mathrm{D} 3$ did not affect the formation of larger colonies $(>0.5 \mathrm{~mm})$ and only diminished the formation of smaller colonies $(0.2-0.5 \mathrm{~mm})$ at concentrations of $10^{-7}$ and $10^{-8}$ M. $1,20(\mathrm{OH})_{2}$ D3 was somewhat more effective with higher doses significantly inhibiting the formation of both small and large colonies. 
WM164 Scramble
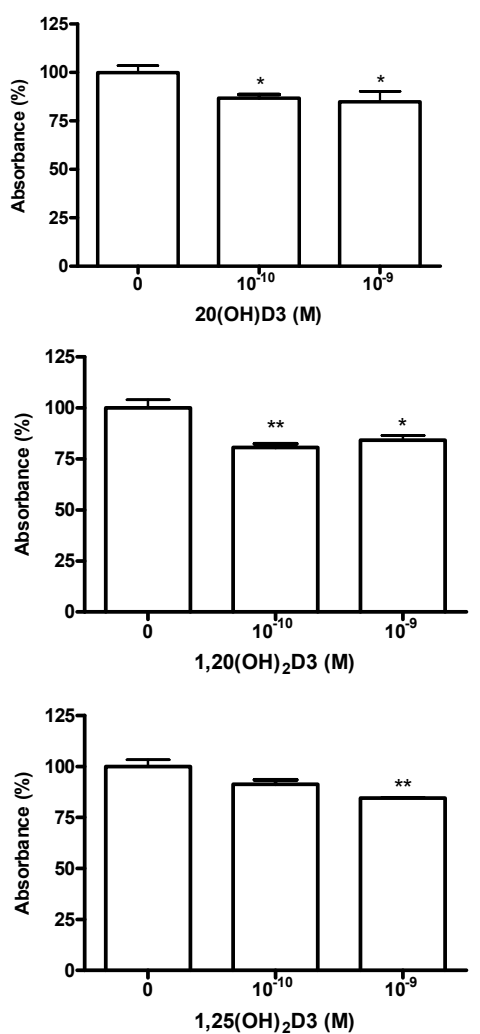

WM164 VDR KO
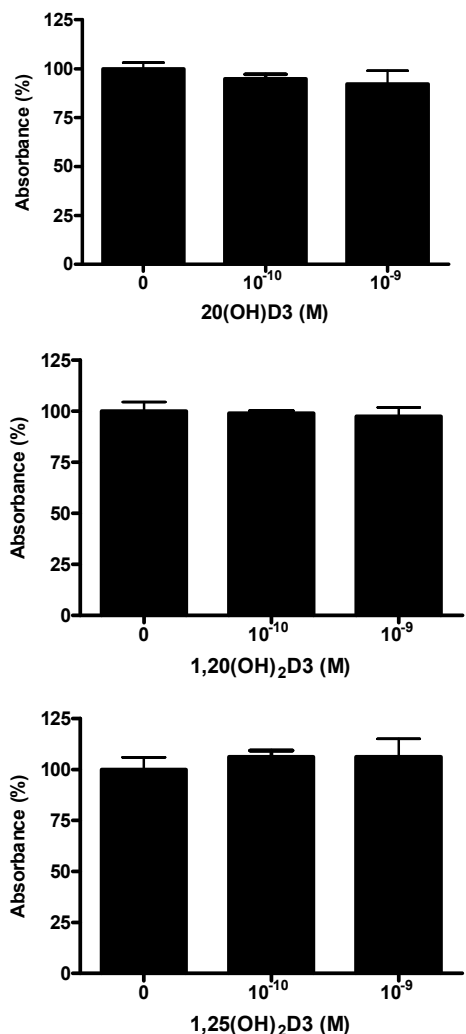

Figure 4. Active forms of vitamin D3 inhibit the proliferation of WM164 cells through the VDR. Both cell types, WM164 scramble and VDR KO cells, were seeded at the same concentration. The MTS assay was performed after $24 \mathrm{~h}$ of incubation with vitamin D3 derivatives. Statistical significance was determined by $t$-test, $p<0.05^{*}, p<0.01^{* *}, n=4$.

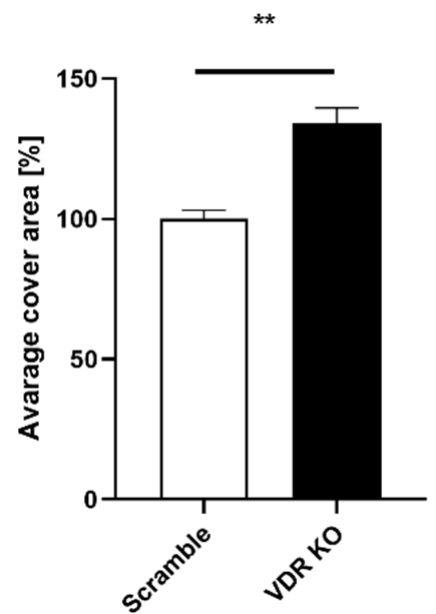

Figure 5. The area occupied by colonies formed after 14 days of incubation of WM164 VDR KO was greater than scramble cells. Cells were seeded at $3 \times 10^{3} /$ well and after 14 days were fixed and dyed with crystal blue. The images of wells were made using a Cytation 5 reader with Gen 5.3 software, and $\%$ area coverage relative to the scramble control $(100 \%)$ was determined. Statistical analysis was via $t$-test, $p<0.01^{* *}, n=6$. 

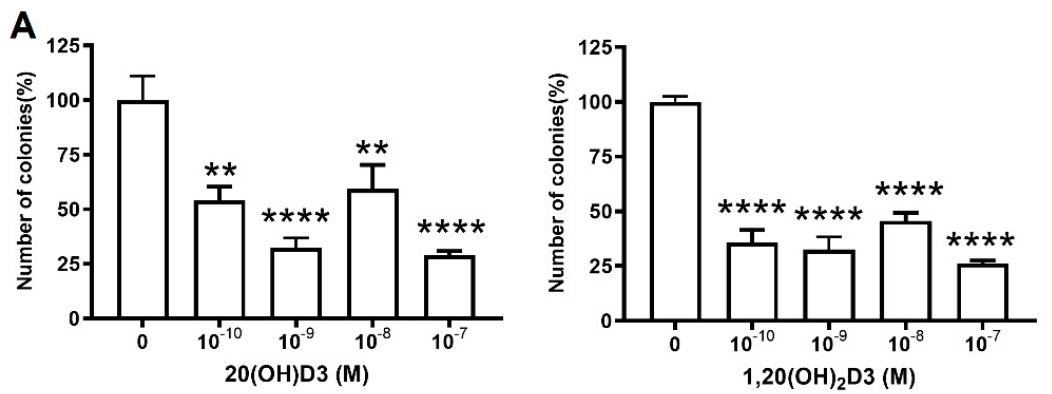

$>0.1 \mathrm{~mm}$
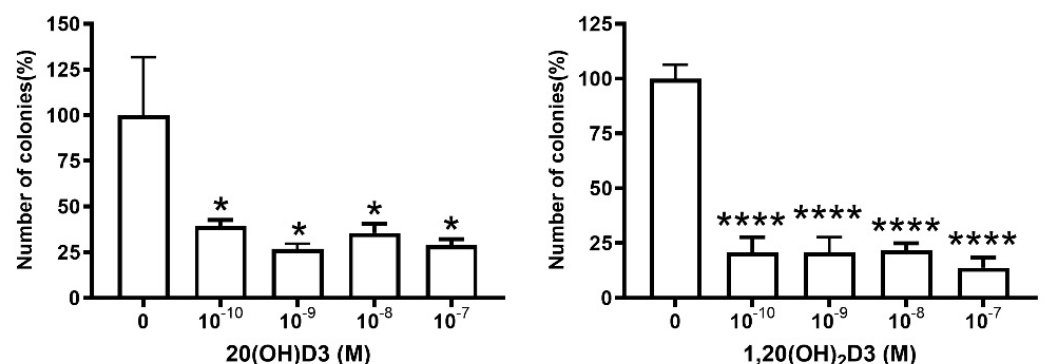

$>0.5 \mathrm{~mm}$

B
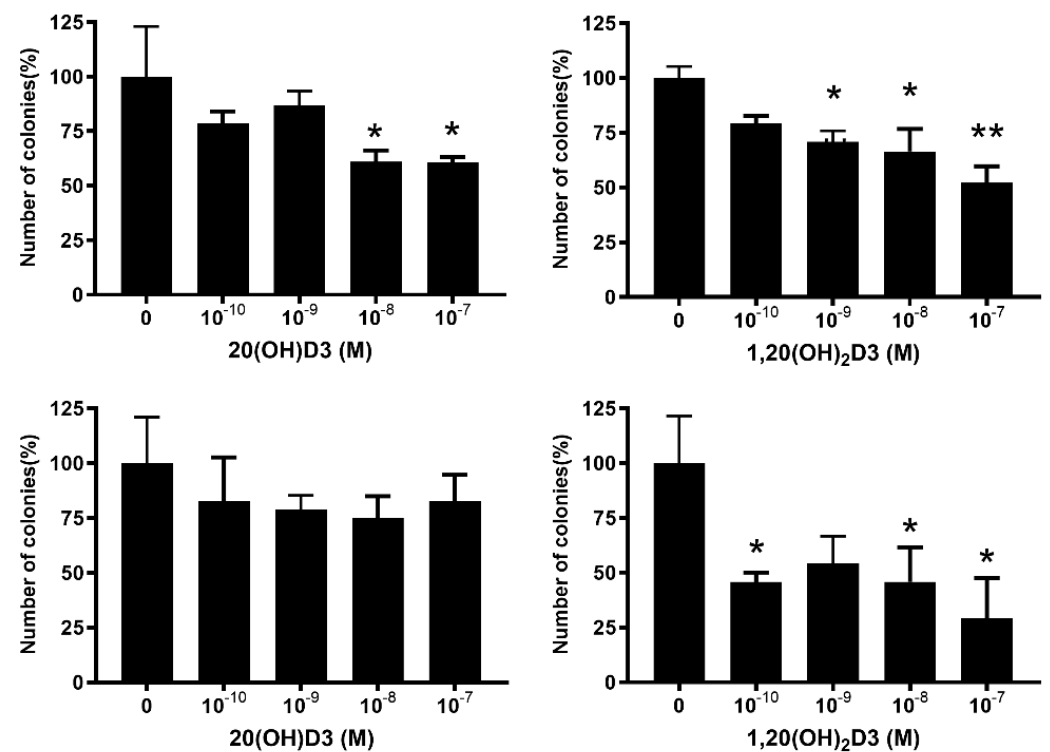

Figure 6. The effect of vitamin D derivatives on the formation of small and large colonies by VDR $\mathrm{KO}$ cells and scramble controls. The number of colonies (\% of ethanol control) with diameters of 0.1-0.5 and $>0.5 \mathrm{~mm}$ for scramble (A) or WM164 VDR KO (B) cells was determined after 7 days of incubation with $1,20(\mathrm{OH})_{2} \mathrm{D} 3$ or $20(\mathrm{OH}) \mathrm{D} 3$ at the indicated concentrations. One-way ANOVA showed significant differences: $p<0.05^{*}, p<0.01^{* *}, p<0.0001^{* * * *}, n=6$.

The ability of WM164 VDR KO cells and scramble control cells to form spheroids was used as an indicator of the tumor-forming properties of these cells. Initially we determined the relationship between the number of seeded cells and the number of spheroids formed over a 7-day incubation period. Cells were seeded at numbers ranging between 125 and 10,000 . With higher numbers of seeded cells $(5000-10,000)$, significantly more spheroids were formed by the VDR KO cells than the scramble controls (Figure 7). Incubation of VDR KO cells with vitamin D3 derivatives at $10^{-7} \mathrm{M}$ revealed that only $1,20(\mathrm{OH})_{2} \mathrm{D} 3$ significantly reduced the number of spheroids formed, whereas a reduction was seen for the WM164 scramble cells with both $20(\mathrm{OH}) \mathrm{D} 3$ and $1,20(\mathrm{OH})_{2} \mathrm{D} 3$ (Figure 8). 


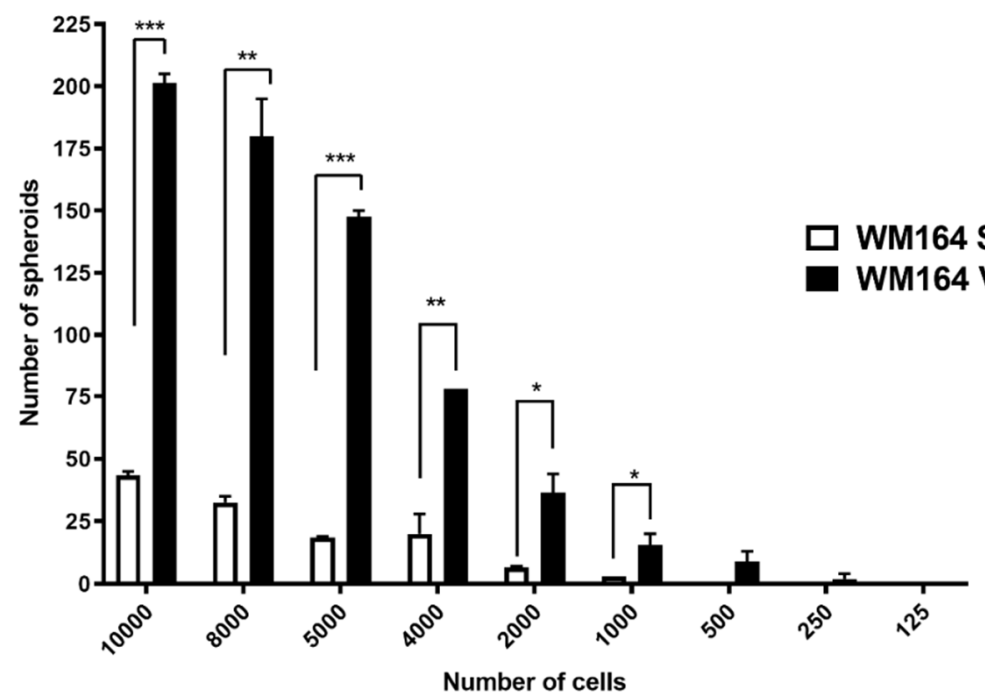

Figure 7. Relationship between the number of seeded cells and spheroid formation for WM164 VDR KO and scramble cells. Cell were seeded in numbers ranging from 125 to 10,000 cells/well, as indicated, and incubated for 7 days. Statistical analysis was conducted using the $t$-test, $p<0.05^{*}$, $p<0.01^{* *}, p<0.001^{* * *}, n=6$.
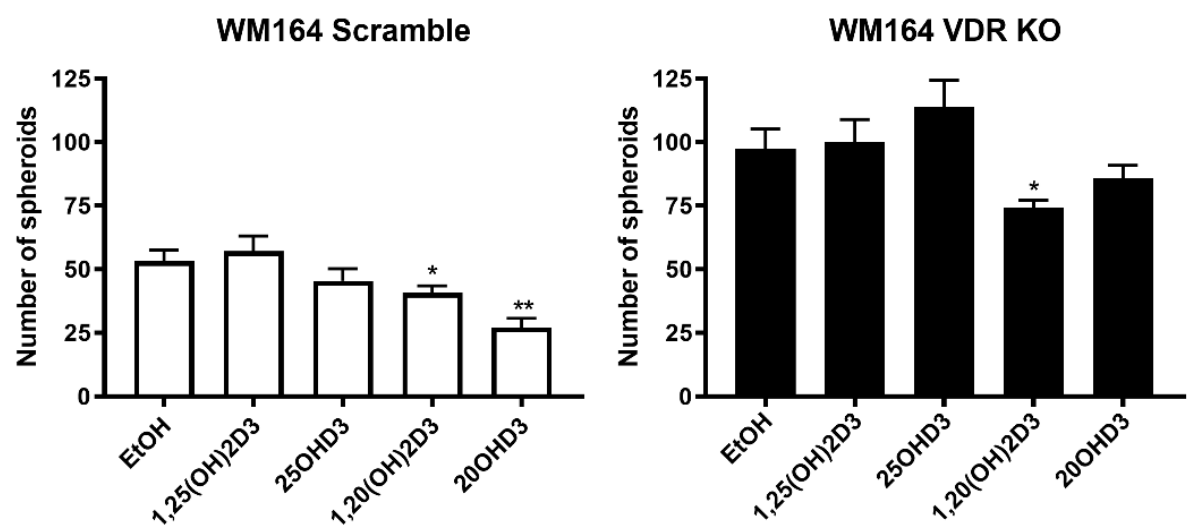

Figure 8. The effect of vitamin D derivatives on spheroid formation by WM164 VDR KO and scramble cells. Both cell types were seeded at 2000 per well and incubated with secosteroids, as indicated, at $10^{-7} \mathrm{M}$ for 7 days. The respective ethanol vehicle controls were used for evaluating statistical differences for the secosteroid treatments. Differences vs. ethanol control were analyzed using the $t$-test, $p<0.05^{*}, p<0.01^{* *}, n=6$.

\subsection{VDR Expression Affects Cell Migration}

To compare the migration abilities of VDR KO and scrambled cells, the extent by which the cells could fill a "scratched" area of the culture well was determined (Figures 9 and 10). Incubation of WM164 scramble cells with the four vitamin D3 derivatives significantly reduced this area to less than $50 \%$ by the end of $70 \mathrm{~h}$ (Figure 9 ). After $70 \mathrm{~h}$ of incubation with the ethanol vehicle (control), the VDR KO type cells covered $90 \%$ of the scratch area, while scramble cells covered only $75 \%$ of the area (Figure 10). The incubation of VDR $\mathrm{KO}$ cells with vitamin D3 derivatives had a much smaller effect on the coverage of the scratch area. 

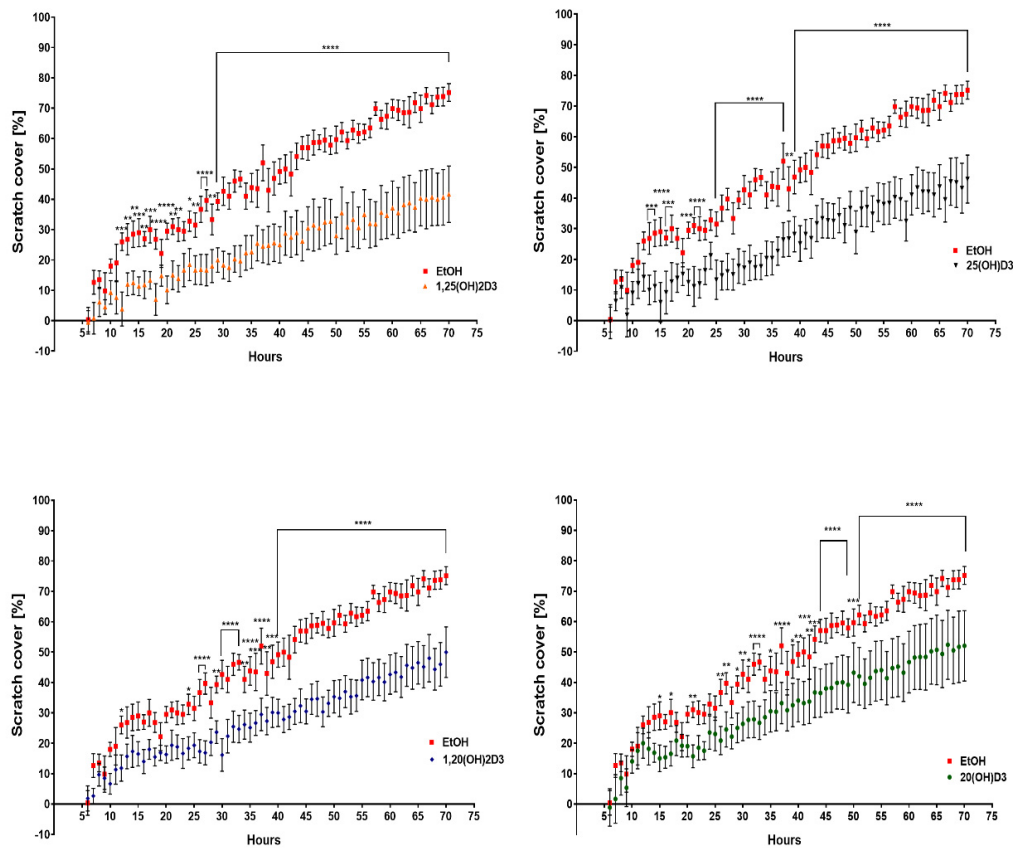

Figure 9. The effect of vitamin D derivatives on the migration of WM164 scramble cells determined with the scratch assay. Movement of cells into the scratch area was observed over $70 \mathrm{~h}$ of incubation with secosteroids at $10^{-7} \mathrm{M}$ or the ethanol vehicle as control. Pictures of the scratch area were taken every hour for $70 \mathrm{~h}$ using a Cytation 5 instrument and were analyzed using Gen 5.3 software (BioTek, Winooski, VT, USA), two-way ANOVA, $p<0.05^{*}, p<0.01^{* *}, p<0.001^{* * *}, p<0.0001^{* * *}, n=7$. The line defines all time points with the same statistical significance.
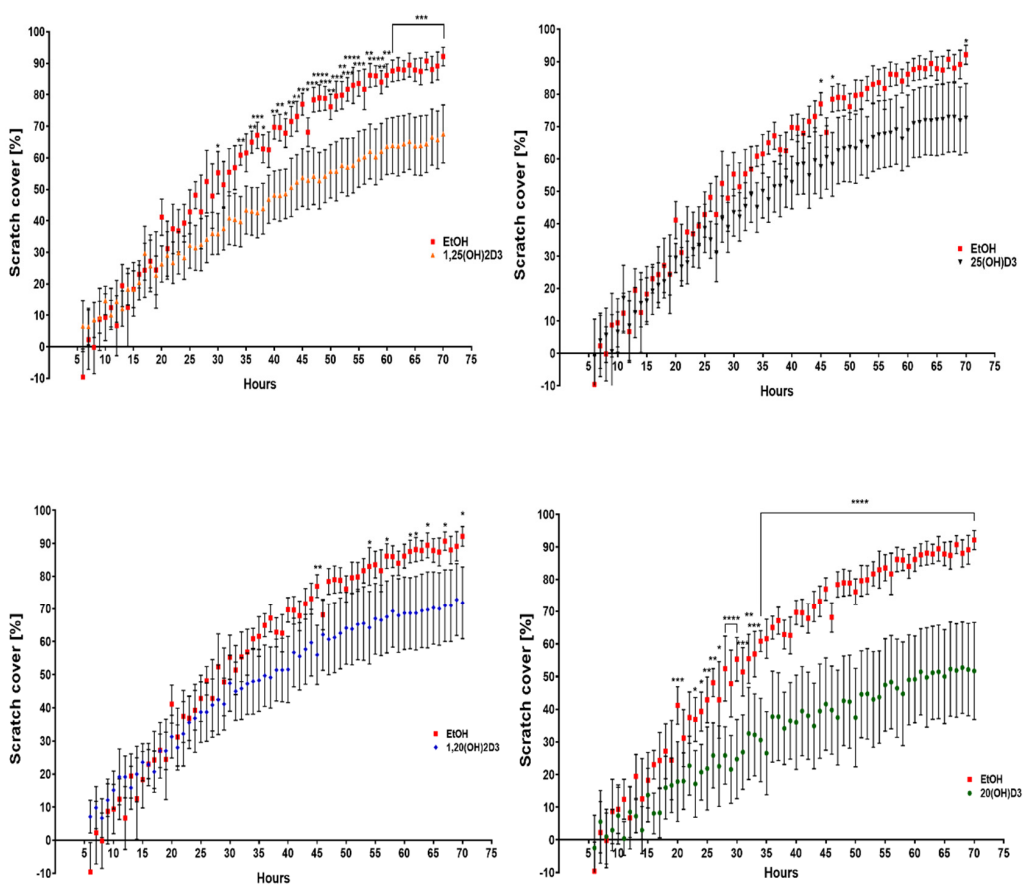

Figure 10. The effect of vitamin D derivatives on the migration of VDR KO type WM164 determined with the scratch assay. Movement of cells into the scratch area was observed over $70 \mathrm{~h}$ of incubation with secosteroids at $10^{-7} \mathrm{M}$ or the ethanol vehicle as control. Pictures of the scratch area were taken every hour for $70 \mathrm{~h}$ using a Cytation 5 instrument and were analyzed using Gen 5.3 software (BioTek, Winooski, VT, USA), two-way ANOVA, $p<0.05^{*}, p<0.01^{* *}, p<0.001^{* * *}, p<0.0001^{* * * *}, n=7$. The line defines all time points with the same statistical significance. 


\section{Discussion}

The VDR is implicated in the regulation of an array of biological activities, including development and progression of cancer, for example breast, prostate and ovarian cancers and melanoma [53-55]. Brozyna et al. [31,46] showed that less advanced tumors exhibited significantly higher VDR expression than those in the advanced stage. In order to explore the role of the VDR in melanoma cells in more depth, we established a melanoma cell line with the expression of the VDR knocked out and compared this to control cells with a functional VDR. Our results indicate that VDR expression affects the characteristics of the melanoma line originally derived from human skin. Knocking out of VDR expression in the WM164 human skin melanoma cell line not only caused changes in cell morphology but also accelerated the growth rate, as measured by proliferation and colony formation assays. Furthermore, spheroid formation, as an indicator of the tumor-forming ability of the cells, was more prominent in melanoma cells with the VDR knocked out. This is in line with the results of Muralidhar et al. [35] who reported that there is a correlation between expression of VDR and melanoma progression and antitumor immunity. Their findings revealed that higher expression of VDR was correlated with upregulated pathways mediating antitumor immunity and with downregulated proliferative pathways [35]. Other studies have shown the importance of the VDR for protecting against tumor development, such as development of breast cancer in VDR deficient mice [56] and in response to UV irradiation [57]. When VDR KO mice were exposed to UVR, they showed greater stimulation of carcinogenesis than their wild-type siblings, and tumor proliferation continued to increase for at least 48 $\mathrm{h}$, while tumor proliferation in wild-type mice reached a plateau after $24 \mathrm{~h}$ [58]. Similarly, Sertznig et al. [59] showed that the expression of VDR was stronger in the $1,25(\mathrm{OH})_{2} \mathrm{D} 3-$ sensitive melanoma cells such as MeWo and SK-Mel-28, compared to 1,25(OH $)_{2}$ D3-resistant melanoma cell lines such as SK-Mel-5 and SK-Mel-25. They also reported that treatment with $1,25(\mathrm{OH})_{2} \mathrm{D} 3$ increased VDR expression in MeWo and SK-Mel-28 cells but not in SK-Mel-5 and SK-Mel-25 cell lines. Similar to the case of breast cancer which has a higher predisposition to growth and the development of metastases [60], our study shows that WM164 VDR KO cells proliferate and migrate faster than the control scramble cells type.

Oda and colleagues supported the above in vivo studies with in vitro ones where the expression of VDR and the DRIP205 coactivator were decreased. They showed that the lack of the VDR was associated with an increase in proliferation and a reduction of the differentiation of human keratinocytes [61]. Another study [48] confirmed that the expression of the vitamin $\mathrm{D}$ receptor in breast cancer patients was inversely proportional to tumor aggressiveness, including tumor size. There was also a correlation between the 25(OH)D3 serum concentration and risk of aggressive breast tumor. High VDR expression determined a less malignant phenotype and was associated with better prognosis. The loss of VDR affected tumor melanoma behavior, allowing disease progression, thus making VDR expression a prognostic marker for routine histopathological evaluation [46].

Our previous studies show that novel CYP11A1-derived vitamin D derivatives inhibit proliferation of different cells, including melanoma [38]. In the current study we show that these vitamin $\mathrm{D}_{3}$ hydroxyderivatives, $1,20(\mathrm{OH})_{2} \mathrm{D} 3$ and $20(\mathrm{OH}) \mathrm{D} 3$, inhibit the proliferation of human WM164 melanoma cells, with a similar effect to the already characterized $1,25(\mathrm{OH})_{2}$ D3. This supports that the recently uncovered pathways for the synthesis of these hydroxyderivatives from vitamin D3 represent alternative ways by which vitamin D3 can be activated. We also demonstrate that knocking out VDR expression in human skin melanoma cells increases their proliferation and colony and spheroid formation capacity. This suggests that expression of VDR is connected with the tumor malignancy of human skin melanoma. This opens new possibilities in the methods of diagnosis and treatment of not only skin melanomas but also other cancers.

Significant effects of $20(\mathrm{OH}) \mathrm{D} 3$ and $1,20(\mathrm{OH})_{2} \mathrm{D} 3$ on the WM164 melanoma cells lacking VDR expression, shown in this study, support recent findings that other receptors besides the VDR mediate some of the effects of vitamin D derivatives [24,62-65]. Our results support previous observations by Brożyna et al. [31,46,66,67] and Markiewicz et al. [68] 
that VDR expression in patient melanoma samples can help with the prognosis and choice of the best therapy. These findings are also consistent with several studies that provide evidence for a role of vitamin D signaling in melanoma prevention and attenuation of disease severity $[35,36,47,66,69-72]$. It must also be noted that VDR is considered as a tumor suppressor in cutaneous carcinogenesis [58,73,74]. Based on the above as well as on the current data, we propose that the VDR is also a tumor suppressor in melanoma. However, further research into the effects of the non-calcemic $20(\mathrm{OH}) \mathrm{D} 3$ and the low calcemic $1,20(\mathrm{OH})_{2} \mathrm{D} 3$ on cancer lines is necessary to fully validate their potential as therapeutic agents for melanoma therapy.

\section{Conclusions}

Our studies demonstrating that knocking out VDR expression in human melanoma cells increases parameters of malignancy indicate that expression of VDR is connected with an increased malignant behavior in melanoma cells. This is consistent with clinicopathological studies showing an inverse correlation between melanoma progression and VDR expression, with very poor disease outcome in VDR negative melanomas. Therefore, we propose that VDR can act as a melanoma tumor suppressor gene.

Classical $\left(1,25(\mathrm{OH})_{2} \mathrm{D} 3\right)$ and CYP11-derived $\left(20(\mathrm{OH}) \mathrm{D} 3,1,20(\mathrm{OH})_{2} \mathrm{D} 3\right)$ hydroxyderivatives of vitamin $\mathrm{D}$ inhibited cell proliferation, migration rate and the ability to form colonies and spheroids in melanoma cells. Silencing the VDR attenuated these actions, but not completely. Thus, vitamin D3 hydroxyderivatives are good candidates for melanoma therapy with their main mechanism of action involving VDR; however, action on other nuclear receptors cannot be excluded and remains to be investigated. These findings form a basis for future preclinical studies on the efficacy of CYP11A1-derivatives against human melanomas.

Supplementary Materials: The following are available online at https:/ /www.mdpi.com/article/10 $.3390 /$ cancers13133111/s1, Figure S1: Western blot analysis for VDR and $\beta$-actin protein expressions in scrambled and VDR knockout WM-164 melanoma cells.

Author Contributions: E.P. designed and the collected the data, performed data analysis, prepared the manuscript; T.-K.K. designed the analysis, collected the data, performed data analysis and edited and revised the text; Z.J. contributed to data analysis and edited and revised the text; K.U. responsible for the concept of the paper and edited and revised the text; R.C.T. prepared derivatives and edited and revised the text; S.B. statistical analysis and edited and revised the text; A.T.S. conceptualization, data analysis, writing - review and editing, supervision, funding acquisition. All authors have read and agreed to the published version of the manuscript.

Funding: This research was supported by NIH grants 1R01AR073004-01A1, R01AR071189-01A1, P30 CA13148 and a VA merit grant (no. 1101BX004293-01A1).

Institutional Review Board Statement: Not applicable.

Informed Consent Statement: Not applicable.

Data Availability Statement: The data presented in this study are available on reasonable request from the corresponding author.

Acknowledgments: The paper is dedicated to the memory of John M. Pawelek, the co-founder of the Pigment Cell Societies.

Conflicts of Interest: The authors declare no conflict of interest.

\section{References}

1. Holick, M.F. Vitamin D and bone health. J. Nutr. 1996, 126, 1159S-1164S. [CrossRef] [PubMed]

2. Holick, M. The use and interpretation of assays for vitamin D and its metabolites. J. Nutr. 1990, 120, 1464-1469. [CrossRef]

3. Slominski, A.T.; Janjetovic, Z.; Fuller, B.E.; Zmijewski, M.A.; Tuckey, R.C.; Nguyen, M.N.; Sweatman, T.; Li, W.; Zjawiony, J.; Miller, D.; et al. Products of vitamin D3 or 7-dehydrocholesterol metabolism by cytochrome P450scc show anti-leukemia effects, having low or absent calcemic activity. PLoS ONE 2010, 5, e9907. [CrossRef] 
4. Slominski, A.T.; Zmijewski, M.A.; Płonka, P.; Szaflarski, J.P.; Paus, R. How UV light touches the brain and endocrine system through skin, and why. Endocrinology 2018, 159, 1992-2007. [CrossRef] [PubMed]

5. Dattola, A.; Silvestri, M.; Bennardo, L.; Passante, M.; Scali, E.; Patruno, C.; Nisticò, S.P. Role of vitamins in skin health: A systematic review. Curr. Nutr. Rep. 2020, 9, 226-235. [CrossRef]

6. Holick, M.F. Viamin D: A millenium perspective. J. Cell. Biochem. 2003, 88, 296-307. [CrossRef]

7. Lips, P. Vitamin D physiology. Prog. Biophys. Mol. Biol. 2006, 92, 4-8. [CrossRef] [PubMed]

8. Holick, M.F.; Chen, T.C. Vitamin D deficiency: A worldwide problem with health consequences. Am. J. Clin. Nutr. 2008, 87, 1080S-1086S. [CrossRef]

9. Reichrath, J. Vitamin D and the skin: An ancient friend, revisited. Exp. Dermatol. 2007, 16, 618-625. [CrossRef]

10. Bikle, D.D. Vitamin D: An ancient hormone. Exp. Dermatol. 2010, 20, 7-13. [CrossRef] [PubMed]

11. Holick, M.F. Vitamin D deficiency. N. Engl. J. Med. 2007, 357, 266-281. [CrossRef] [PubMed]

12. Jones, G.; Prosser, D.E.; Kaufmann, M. Cytochrome P450-mediated metabolism of vitamin D. J. Lipid Res. 2014, 55, 13-31. [CrossRef]

13. Schuster, I. Cytochromes P450 are essential players in the vitamin D signaling system. Biochim. Biophys. Acta BBA Proteins Proteom. 2011, 1814, 186-199. [CrossRef]

14. Tsuprykov, O.; Chen, X.; Hocher, C.-F.; Skoblo, R.; Yin, L.; Hocher, B. Why should we measure free 25(OH) vitamin D? J. Steroid Biochem. Mol. Biol. 2018, 180, 87-104. [CrossRef]

15. Slominski, A.T.; Kim, T.; Shehabi, H.Z.; Semak, I.; Tang, E.K.Y.; Nguyen, M.N.; Benson, H.A.E.; Korik, E.; Janjetovic, Z.; Chen, J.; et al. In vivo evidence for a novel pathway of vitamin $\mathrm{D}_{3}$ metabolism initiated by P450scc and modified by CYP27B1. FASEB J. 2012, 26, 3901-3915. [CrossRef]

16. Slominski, A.T.; Kim, T.-K.; Li, W.; Tuckey, R.C. Classical and non-classical metabolic transformation of vitamin D in dermal fibroblasts. Exp. Dermatol. 2015, 25, 231-232. [CrossRef]

17. Slominski, A.T.; Zmijewski, M.A.; Semak, I.; Sweatman, T.; Janjetovic, Z.; Li, W.; Zjawiony, J.K.; Tuckey, R.C. Sequential metabolism of 7-dehydrocholesterol to steroidal 5,7-dienes in adrenal glands and its biological implication in the skin. PLoS ONE 2009, 4, e4309. [CrossRef] [PubMed]

18. Zbytek, B.; Janjetovic, Z.; Tuckey, R.C.; Zmijewski, M.A.; Sweatman, T.W.; Jones, E.; Nguyen, M.N.; Slominski, A.T. 20hydroxyvitamin D3, a product of vitamin D3 hydroxylation by cytochrome P450scc, stimulates keratinocyte differentiation. J. Investig. Dermatol. 2008, 128, 2271-2280. [CrossRef]

19. Miller, W.L.; Auchus, R.J. The molecular biology, biochemistry, and physiology of human steroidogenesis and its disorders. Endocr. Rev. 2011, 32, 81-151. [CrossRef]

20. Slominski, R.M.; Raman, C.; Elmets, C.; Jetten, A.M.; Slominski, A.T.; Tuckey, R. The significance of CYP11A1 expression in skin physiology and pathology. Mol. Cell. Endocrinol. 2021, 530, 111238. [CrossRef] [PubMed]

21. Slominski, R.M.; Tuckey, R.C.; Manna, P.R.; Jetten, A.M.; Postlethwaite, A.; Raman, C.; Slominski, A.T. Extra-adrenal glucocorticoid biosynthesis: Implications for autoimmune and inflammatory disorders. Genes Immun. 2020, 21, 150-168. [CrossRef] [PubMed]

22. Slominski, A.T.; Kim, T.-K.; Li, W.; Yi, A.-K.; Postlethwaite, A.; Tuckey, R.C. The role of CYP11A1 in the production of vitamin D metabolites and their role in the regulation of epidermal functions. J. Steroid Biochem. Mol. Biol. 2014, 144, 28-39. [CrossRef]

23. Tuckey, R.C.; Cheng, C.Y.; Slominski, A.T. The serum vitamin D metabolome: What we know and what is still to discover. J. Steroid Biochem. Mol. Biol. 2019, 186, 4-21. [CrossRef] [PubMed]

24. Slominski, A.T.; Chaiprasongsuk, A.; Janjetovic, Z.; Kim, T.K.; Stefan, J.; Slominski, R.M.; Hanumanthu, V.S.; Raman, C.; Qayyum, S.; Song, Y.; et al. Photoprotective properties of vitamin D and Lumisterol hydroxyderivatives. Cell Biochem. Biophys. 2020, 78, 165-180. [CrossRef]

25. Slominski, A.T.; Li, W.; Kim, T.-K.; Semak, I.; Wang, J.; Zjawiony, J.K.; Tuckey, R.C. Novel activities of CYP11A1 and their potential physiological significance. J. Steroid Biochem. Mol. Biol. 2015, 151, 25-37. [CrossRef]

26. Slominski, A.T.; Brożyna, A.A.; Zmijewski, M.A.; Jóźwicki, W.; Jetten, A.; Mason, R.S.; Tuckey, R.C.; Elmets, C.A. Vitamin D signaling and melanoma: Role of vitamin D and its receptors in melanoma progression and management. Lab. Investig. 2017, 97, 706-724. [CrossRef]

27. Fleet, J.C.; Desmet, M.; Johnson, R.; Li, Y. Vitamin D and cancer: A review of molecular mechanisms. Biochem. J. 2011, 441, 61-76. [CrossRef]

28. Lehmann, B. Role of the vitamin D3pathway in healthy and diseased skin-Facts, contradictions and hypotheses. Exp. Dermatol. 2009, 18, 97-108. [CrossRef] [PubMed]

29. Colston, K.; Colston, M.J.; Feldman, D. 1,25-dihydroxyvitamin D3 and malignant melanoma: The presence of receptors and inhibition of cell growth in culture. Endocrinology 1981, 108, 1083-1086. [CrossRef]

30. Lombardo, N.; Della Corte, M.; Pelaia, C.; Piazzetta, G.; Lobello, N.; Del Duca, E.; Bennardo, L.; Nisticò, S. Primary mucosal melanoma presenting with a unilateral nasal obstruction of the left inferior turbinate. Medicina 2021, 57, 359. [CrossRef] [PubMed]

31. Brożyna, A.A.; Jozwicki, W.; Janjetovic, Z.; Slominski, A.T. Expression of vitamin D receptor decreases during progression of pigmented skin lesions. Hum. Pathol. 2011, 42, 618-631. [CrossRef] [PubMed]

32. Jozwicki, W.; Brozyna, A.A.; Siekiera, J.; Slominski, A.T. Expression of vitamin D receptor (VDR) positively correlates with survival of urothelial bladder cancer patients. Int. J. Mol. Sci. 2015, 16, 24369-24386. [CrossRef] [PubMed] 
33. Huss, L.; Butt, S.T.; Borgquist, S.; Elebro, K.; Sandsveden, M.; Rosendahl, A.; Manjer, J. Vitamin D receptor expression in invasive breast tumors and breast cancer survival. Breast Cancer Res. 2019, 21, 1-13. [CrossRef] [PubMed]

34. Gheliji, T.; Oskooei, V.K.; Hafez, A.A.; Taheri, M.; Ghafouri-Fard, S. Evaluation of expression of vitamin D receptor related lncRNAs in lung cancer. Non-Coding RNA Res. 2020, 5, 83-87. [CrossRef] [PubMed]

35. Muralidhar, S.; Filia, A.; Nsengimana, J.; Pozniak, J.; O'Shea, S.J.; Diaz, J.M.; Harland, M.; Randerson-Moor, J.A.; Reichrath, J.; Laye, J.P.; et al. Vitamin D_VDR signaling inhibits wnt/beta-catenin-mediated melanoma progression and promotes antitumor immunity. Cancer Res. 2019, 79, 5986-5998. [CrossRef] [PubMed]

36. Slominski, A.T.; Brozyna, A.A.; Skobowiat, C.; Zmijewski, M.A.; Kim, T.-K.; Janjetovic, Z.; Oak, A.S.; Jozwicki, W.; Jetten, A.M.; Mason, R.S.; et al. On the role of classical and novel forms of vitamin D in melanoma progression and management. J. Steroid. Biochem. Mol. Biol. 2018, 177, 159-170. [CrossRef] [PubMed]

37. Skobowiat, C.; Oak, A.S.; Kim, T.-K.; Yang, C.H.; Pfeffer, L.; Tuckey, R.C.; Slominski, A.T. Noncalcemic 20-hydroxyvitamin D3 inhibits human melanoma growth in in vitro and in vivo models. Oncotarget 2016, 8, 9823-9834. [CrossRef] [PubMed]

38. Slominski, A.T.; Janjetovic, Z.; Kim, T.-K.; Wright, A.C.; Grese, L.N.; Riney, S.J.; Nguyen, M.N.; Tuckey, R.C. Novel vitamin D hydroxyderivatives inhibit melanoma growth and show differential effects on normal melanocytes. Anticancer Res. 2012, 32, 3733-3742.

39. Szyszka, P.; Zmijewski, M.A.; Slominski, A.T. New vitamin D analogs as potential therapeutics in melanoma. Expert Rev. Anticancer Ther. 2012, 12, 585-599. [CrossRef] [PubMed]

40. Chen, J.; Wang, J.; Kim, T.-K.; Tieu, E.W.; Tang, E.K.; Lin, Z.; Kovacic, D.; Miller, D.D.; Postlethwaite, A.; Tuckey, R.C.; et al. Novel vitamin D analogs as potential therapeutics: Metabolism, toxicity profiling, and antiproliferative activity. Anticancer Res. 2014, 34, 2153-2163. [PubMed]

41. Wasiewicz, T.; Piotrowska, A.; Wierzbicka, J.; Slominski, A.T.; Zmijewski, M.A. Antiproliferative activity of non-calcemic vitamin D analogs on human melanoma lines in relation to VDR and PDIA3 receptors. Int. J. Mol. Sci. 2018, 19, 2583. [CrossRef] [PubMed]

42. Newton-Bishop, J.A.; Beswick, S.; Randerson-Moor, J.; Chang, Y.-M.; Affleck, P.; Elliott, F.; Chan, M.; Leake, S.; Karpavicius, B.; Haynes, S.; et al. Serum 25-hydroxyvitamin D3 levels are associated with breslow thickness at presentation and survival from melanoma. J. Clin. Oncol. 2009, 27, 5439-5444. [CrossRef] [PubMed]

43. Nürnberg, B.; Gräber, S.; Gärtner, B.; Geisel, J.; Pföhler, C.; Schadendorf, D.; Tilgen, W.; Reichrath, J. Reduced serum 25hydroxyvitamin D levels in stage IV melanoma patients. Anticancer Res. 2009, 29, 3669-3674. [PubMed]

44. Gambichler, T.; Bindsteiner, M.; Höxtermann, S.; Kreuter, A. Serum 25-hydroxyvitamin D serum levels in a large German cohort of patients with melanoma. Br. J. Dermatol. 2013, 168, 625-628. [CrossRef]

45. Jeon, S.-M.; Shin, E.-A. Exploring vitamin D metabolism and function in cancer. Exp. Mol. Med. 2018, 50, 1-14. [CrossRef]

46. Brożyna, A.A.; Jóźwicki, W.; Slominski, A.T. Decreased VDR expression in cutaneous melanomas as marker of tumor progression: New data and analyses. Anticancer Res. 2014, 34, 2735-2743.

47. Slominski, A.T.; Brozyna, A.A.; Zmijewski, M.A.; Janjetovic, Z.; Kim, T.K.; Slominski, R.M.; Tuckey, R.C.; Mason, R.; Jetten, A.M.; Reichrath, J.; et al. The role of classical and novel forms of vitamin D in the pathogenesis and progression of non-melanoma skin cancers. Adv. Exp. Med. Biol. 2020, 1268, 257-283.

48. Al-Azhri, J.; Zhang, Y.; Bshara, W.; Zirpoli, G.R.; McCann, S.E.; Khoury, T.; Morrison, C.D.; Edge, S.B.; Ambrosone, C.B.; Yao, S. Tumor expression of vitamin D receptor and breast cancer histopathological characteristics and prognosis. Clin. Cancer Res. 2017, 23, 97-103. [CrossRef] [PubMed]

49. Evans, S.R.; Nolla, J.; Hanfelt, J.; Shabahang, M.; Nauta, R.J.; Shchepotin, I.B. Vitamin D receptor expression as a predictive marker of biological behavior in human colorectal cancer. Clin. Cancer Res. 1998, 4, 1591-1595.

50. Tuckey, R.C.; Janjetovic, Z.; Li, W.; Nguyen, M.N.; Zmijewski, M.A.; Zjawiony, J.; Slominski, A. Metabolism of $1 \alpha$-hydroxyvitamin D3 by cytochrome P450scc to biologically active 1 1 ,20-dihydroxyvitamin D3. J. Steroid Biochem. Mol. Biol. 2008, 112, $213-219$. [CrossRef]

51. Tuckey, R.C.; Li, W.; Shehabi, H.Z.; Janjetovic, Z.; Nguyen, M.N.; Kim, T.-K.; Chen, J.; Howell, D.E.; Benson, H.A.E.; Sweatman, T.; et al. Production of 22-hydroxy metabolites of vitamin D3 by cytochrome P450scc (CYP11A1) and analysis of their biological activities on skin cells. Drug Metab. Dispos. 2011, 39, 1577-1588. [CrossRef] [PubMed]

52. Janjetovic, Z.; Brozyna, A.A.; Tuckey, R.C.; Kim, T.K.; Nguyen, M.N.; Jozwicki, W.; Pfeffer, S.R.; Pfeffer, L.M.; Slominski, A.T. High basal NF-kappaB activity in nonpigmented melanoma cells is associated with an enhanced sensitivity to vitamin D3 derivatives. Br. J. Cancer 2011, 105, 1874-1884. [CrossRef] [PubMed]

53. Lopes, N.; Sousa, B.; Martins, D.; Gomes, M.; Vieira, D.; Veronese, L.A.; Milanezi, F.; Paredes, J.; Costa, J.L.; Schmitt, F. Alterations in vitamin D signalling and metabolic pathways in breast cancer progression: A study of VDR, CYP27B1 and CYP24A1 expression in benign and malignant breast lesions vitamin D pathways unbalanced in breast lesions. BMC Cancer 2010, 10, 483. [CrossRef] [PubMed]

54. Zhang, Y.-D.; Zhao, H.; Li, K.-J.; Guan, R.-Y. Effect of silencing the VDR gene on the migration and invasion of prostate cancer cells. Natl. J. Androl. 2017, 23, 969-974.

55. Brożyna, A.A.; Kim, T.-K.; Zabłocka, M.; Jóźwicki, W.; Yue, J.; Tuckey, R.C.; Jetten, A.M.; Slominski, A.T. Association among vitamin D, retinoic acid-related orphan receptors, and vitamin D hydroxyderivatives in ovarian cancer. Nutrients 2020, 12, 3541. [CrossRef] 
56. Zinser, G.M.; Sundberg, J.P.; Welsh, J. Vitamin D3 receptor ablation sensitizes skin to chemically induced tumorigenesis. Carcinogenesis 2002, 23, 2103-2109. [CrossRef]

57. Ellison, T.I.; Smith, M.K.; Gilliam, A.C.; MacDonald, P.N. Inactivation of the vitamin D Receptor enhances susceptibility of murine skin to UV-induced tumorigenesis. J. Investig. Dermatol. 2008, 128, 2508-2517. [CrossRef]

58. Bikle, D.D.; Elalieh, H.; Welsh, J.; Oh, D.; Cleaver, J.; Teichert, A. Protective role of vitamin D signaling in skin cancer formation. J. Steroid Biochem. Mol. Biol. 2013, 136, 271-279. [CrossRef]

59. Sertznig, P.; Seifert, M.; Tilgen, W.; Reichrath, J. Activation of vitamin D receptor (VDR)- and peroxisome proliferator-activated receptor (PPAR)-signaling pathways through 1,25(OH)2D3 in melanoma cell lines and other skin-derived cell lines. Derm. Endocrinol. 2009, 1, 232-238. [CrossRef]

60. Williams, J.D.; Aggarwal, A.; Swami, S.; Krishnan, A.V.; Ji, L.; Albertelli, M.; Feldman, B.J. Tumor autonomous effects of vitamin D deficiency promote breast cancer metastasis. Endocrinology 2016, 157, 1341-1347. [CrossRef]

61. Oda, Y.; Ishikawa, M.H.; Hawker, N.P.; Yun, Q.-C.; Bikle, D.D. Differential role of two VDR coactivators, DRIP205 and SRC-3, in keratinocyte proliferation and differentiation. J. Steroid Biochem. Mol. Biol. 2007, 103, 776-780. [CrossRef] [PubMed]

62. Slominski, A.T.; Kim, T.-K.; Janjetovic, Z.; Brożyna, A.A.; Żmijewski, M.A.; Xu, H.; Sutter, T.R.; Tuckey, R.C.; Jetten, A.M.; Crossman, D.K. Differential and overlapping effects of 20,23(OH)2D3 and 1,25(OH)2D3 on gene expression in human epidermal keratinocytes: Identification of AhR as an alternative receptor for 20,23(OH)2D3. Int. J. Mol. Sci. 2018, 19, 3072. [CrossRef]

63. Slominski, A.T.; Kim, T.K.; Takeda, Y.; Janjetovic, Z.; Brozyna, A.A.; Skobowiat, C.; Wang, J.; Postlethwaite, A.; Li, W.; Tuckey, R.C.; et al. RORalpha and ROR gamma are expressed in human skin and serve as receptors for endogenously produced noncalcemic 20-hydroxy- and 20,23-dihydroxyvitamin D. FASEB J. 2014, 28, 2775-2789. [CrossRef]

64. Zmijewski, M.A.; Carlberg, C. Vitamin D receptor(s): In the nucleus but also at membranes? Exp. Dermatol. 2020, $29,876-884$. [CrossRef]

65. Slominski, A.T.; Kim, T.-K.; Qayyum, S.; Song, Y.; Janjetovic, Z.; Oak, A.S.W.; Slominski, R.M.; Raman, C.; Stefan, J.; Mier-Aguilar, C.A.; et al. Vitamin D and lumisterol derivatives can act on liver X receptors (LXRs). Sci. Rep. 2021, 11, 8002. [CrossRef]

66. Brożyna, A.A.; Hoffman, R.M.; Slominski, A.T. Relevance of vitamin D in melanoma development, progression and therapy. Anticancer Res. 2020, 40, 473-489. [CrossRef] [PubMed]

67. Brozyna, A.A.; Jozwicki, W.; Jetten, A.M.; Slominski, A.T. On the relationship between VDR, RORalpha and RORgamma receptors expression and HIF1-alpha levels in human melanomas. Exp. Dermatol. 2019, 28, 1036-1043. [CrossRef] [PubMed]

68. Markiewicz, A.; Brożyna, A.A.; Podgórska, E.; Elas, M.; Urbańska, K.; Jetten, A.M.; Slominski, A.T.; Jóźwicki, W.; OrłowskaHeitzman, J.; Dyduch, G.; et al. Vitamin D receptors (VDR), hydroxylases CYP27B1 and CYP24A1 and retinoid-related orphan receptors (ROR) level in human uveal tract and ocular melanoma with different melanization levels. Sci. Rep. 2019, 9, 1-13. [CrossRef] [PubMed]

69. Morgado-Águila, C.; Rey-Sánchez, P.; Gil-Fernández, G.; Costa-Fernández, M.C.; Rodríguez-Velasco, F.J. Vitamin D receptor polymorphisms and non-melanoma skin cancer risk: A case-control study. J. Clin. Med. 2020, 9, 3819. [CrossRef]

70. Vasilovici, A.F.; Grigore, L.E.; Ungureanu, L.; Fechete, O.; Candrea, E.; Trifa, A.P.; Vișan, S.; Șenilă, S.; Cosgarea, R. Vitamin D receptor polymorphisms and melanoma (Review). Oncol. Lett. 2018, 17, 4162-4169. [CrossRef] [PubMed]

71. Timerman, D.; McEnery-Stonelake, M.; Joyce, C.; Nambudiri, V.E.; Hodi, F.S.; Claus, E.B.; Ibrahim, N.; Lin, J.Y. Vitamin D deficiency is associated with a worse prognosis in metastatic melanoma. Oncotarget 2016, 8, 6873-6882. [CrossRef]

72. Lim, A.; Shayan, R.; Varigos, G. High serum vitamin D level correlates with better prognostic indicators in primary melanoma: A pilot study. Australas. J. Dermatol. 2017, 59, 182-187. [CrossRef] [PubMed]

73. Bikle, D.D.; Oda, Y.; Tu, C.-L.; Jiang, Y. Novel mechanisms for the vitamin D receptor (VDR) in the skin and in skin cancer. J. Steroid Biochem. Mol. Biol. 2015, 148, 47-51. [CrossRef] [PubMed]

74. Bikle, D.D. The Vitamin D receptor as tumor suppressor in skin. Adv. Exp. Med. Biol. 2020, 93, 285-306. [CrossRef] 